Scientific paper

\title{
Investigation of Recovery of Volatiles of Bidens tripartita L. Using Solid-Phase Extraction Trap in Supercritical Fluid Extraction
}

\author{
Vilma Kaškonienė* and Audrius Maruška \\ Faculty of Natural Sciences, Vytautas Magnus University, Vileikos str. 8, LT-44404, Kaunas, Lithuania \\ Tel. +37037327907, Fax. +37037327908 \\ * Corresponding author: E-mail:v.kaskoniene@gmf.vdu.lt
}

Received: 29-01-2014

\begin{abstract}
Recovery of Bidens tripartita $\mathrm{L}$. volatiles using supercritical $\mathrm{CO}_{2}$ extraction with solid-phase trap was performed in this study. Three aspects were under investigation: the impact of solvent (heptane, methanol or acetonitrile) applied to rinse the analytes from the trap; the impact of the amount of plant material used for extraction; the release of volatiles from plant matrix using multiple extraction. $\alpha$-Pinene, $\mathrm{p}$-cymene, $\beta$-ocimene, and $\beta$-elemene were predominant in all extracts prepared in different ways. $\beta$-ocimene was the major compound (40-46\%) in all extracts regardless of the solvent used. No significant difference in amount of $\alpha$-pinene was observed when different trap desorption solvents were used, while heptane desorbed significantly higher amounts (12-31\%) of other compounds. The volatile composition showed both qualitative and quantitative differences when different amounts of sample material were used. The extraction extent of the main compounds varied between first and repeated extractions.
\end{abstract}

Keywords: Supercritical fluid extraction, solid-phase trap collection, extraction recovery, Bidens tripartita L.

\section{Introduction}

Various methods for extraction of essential oils or volatile compounds from plant material have been used so far. Hydrodistillation is the oldest and the most popular till nowadays. ${ }^{1-3}$ Likens-Nickerson simultaneous steam distillation extraction, ${ }^{4}$ ultrasound-assisted extraction, ${ }^{5}$ microwave extraction, ${ }^{3}$ Soxhlet extraction, ${ }^{2}$ and supercritical fluid extraction ${ }^{2,4}$ methods are also used quite often. None of these methods can be considered as ideal; all of them possess advantages and disadvantages, which may have smaller or bigger impact on identification and interpretation of compositional peculiarities of volatile compounds. Some techniques are time-consuming (such as hydrodistillation), particularly when a large number of samples have to be analyzed; the use of solvent is associated with a loss of volatiles during solvent removal; heating may result in degradation of some compounds. Even small changes in existing method, like temperature, heating or extraction time, pressure changes or polarity of the solvent may drastically change quantitative and qualitative composition of the essential oils.
Supercritical fluid extraction (SFE) is becoming increasingly popular, and it has been established as an environmentally benign technique for separating essential oils because of non-toxic, non-flammable, and non-explosive carbon dioxide which is mostly used as SFE extrahent. Also this method is a simple, inexpensive, relatively fast, effective and virtually solvent-free sample preparation technique, ${ }^{6}$ with automation possibility regarding the equipment used. The analytes can be collected into an empty vessel, to a vessel containing a small volume of organic solvent, to a solidphase trap, or into a cryogenically cooled capillary. ${ }^{6,7}$ Some studies were performed using reverse osmosis membranes for separation of supercritical fluid and analytes. ${ }^{8-10}$ In the case of solid-phase trap, the sample is reconstituted with a rinse solvent which, containing sample fractions, is washed to the output vials. All methods of analytes collection after supercritical fluid extraction have major or minor drawbacks (e.g. volatile compounds could be hardly collected to an empty vial without significant losses).

Supercritical fluid extraction is widely used in food industry (in brewery for the production of hops extract, ${ }^{11-13}$ production of decaffeinated coffee, ${ }^{6,14}$ removal 
of contaminants, ${ }^{14}$ etc.), also cosmetic and pharmaceutical industries. ${ }^{6,7}$ The supercritical fluid extraction efficiency from plants is dependent on many factors: the nature of the sample matrix, solubility of analytes in supercritical fluid, modifiers added to the supercritical fluid in order to change the polarity, sample collection mode and various extraction parameters, e.g. pressure and temperature, extraction time, supercritical fluid flow rate, sample particle size and packing density, amount of water in the sample and drying mode of the sample etc. . $7,15,16$

To our knowledge, this is the first report showing the dependence of volatiles recovery from the plant material on the number of extractions used, on the amount of material used for analysis, and on the trap desorption solvent. Many studies were performed for the optimization of extraction parameters such as supercritical fluid extraction pressure, flow rate, temperature, and extraction time; however no studies focused on the collection of the essential oils were found. Since this step is crucial for the final result of the extraction process which affects both quantitative and qualitative composition of the volatile compounds composition, it is important to investigate and optimize this step of the process deeply. To our knowledge there are no studies on the application of different trap rinse solvents for recovery of volatile compounds and evaluation of multiple extraction taking into account twostepped volatile fraction rinse from the trap.

The aim of this work was to investigate the recovery of volatiles from Bidens tripartita L. by supercritical fluid extraction using solid-phase trap collection of the analytes. This plant was selected for analysis, because Bidens tripartita $\mathrm{L}$. is a medicinal plant with a valuable therapeutic value (antioxidants, antibacterial, antifungal, antiinflamatory), ${ }^{17-19}$ however it is known that composition of biologically active plant compounds depends on the sample preparation and extraction technique. ${ }^{6,20,21}$ Three main tasks were formulated to achieve the aim of the study: (1) to find optimal rinse solvent for removal of analytes from the trap; (2) to evaluate the yield of extraction when different amounts of plant material is used for the extraction; (3) to evaluate the recovery of the main compounds of $B$. tripartita $\mathrm{L}$. using a multiple extraction technique. Reviewing the literature, which deals with supercritical fluid extraction process optimization, the underestimation of extraction itself and in appreciation of any other steps of the process are observed. To authors knowledge so far there were no studies published dealing with the extracted compounds trapping optimization or multistep extraction affect on the quantitative and qualitative results of the process.

\section{Experimental}

\section{1. Plant Material}

The aerial part of B. tripartita L. is commonly known as three-lobe beggarticks or bur-marigold. The identification of the voucher specimen (VO1267) was carried out by Prof. O. Ragažinskiene from the Botanical garden of Vytautas Magnus University. The herb was collected during the flowering period in 2009 and dried in a well-ventilated and shadow place (temperature did not exceed $25{ }^{\circ} \mathrm{C}$ ). The moisture content in the air-dried herb was $9.4 \%$. The herb was grounded before the extraction in order to avoid the loss of volatiles. Whole aerial part was used for the extraction of the volatile compounds.

\section{2. Supercritical $\mathrm{CO}_{2}$ Extraction (SFE)}

SFE experimentation was carried out using Hewlett-Packard 7680T (USA) supercritical fluid extractor (Figure 1). For each experiment the weight of dried and ground plant material was in the range of $0.10-0.80 \mathrm{~g}$. High purity carbon dioxide $99.5 \%$ from JSC AGA (Lithuania) was used. Extraction parameters were as follows: extraction pressure $9.1 \mathrm{MPa}$; extraction chamber temperature $50{ }^{\circ} \mathrm{C}\left(\mathrm{CO}_{2}\right.$ density, $\left.0.30 \mathrm{~g} / \mathrm{ml}\right)$; extraction vessel volume $10 \mathrm{ml}$; static and dynamic extraction times $2 \mathrm{~min}$ and $15 \mathrm{~min}$. respectively; $\mathrm{CO}_{2}$ flow rate $1 \mathrm{ml} / \mathrm{min}$; collection carried out using ODS (octadecylsilica) adsorbent trap $(1 \mathrm{ml})$ at $5{ }^{\circ} \mathrm{C}$; elution was performed with $0.7 \mathrm{ml}\left(1^{\text {st }}\right.$ substep) and with $0.7 \mathrm{ml}$ ( $2^{\text {nd }}$ substep) of proper organic solvent (heptane, methanol or acetonitrile) at $0.7 \mathrm{ml} / \mathrm{min}$ and $45{ }^{\circ} \mathrm{C}$. Heptane $(99 \%)$ was purchased from Fluka (Germany), methanol and acetonitrile (HPLC gradient grade) were from J.T. Baker (The Netherlands). $1 \mu \mathrm{l}$ of extracted oil was injected into gas chromatograph.

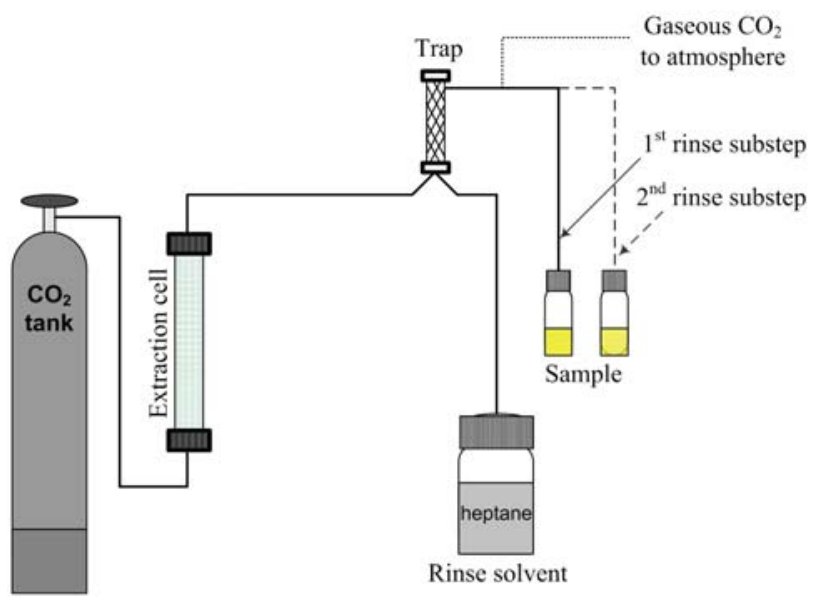

Figure 1. Schematic diagram of supercritical fluid extractor

\section{3. GC/MS Analysis}

Quantitative and qualitative analyses of essential oils were carried out using gas chromatograph GC-2010 (Shimadzu, Japan) with the mass spectrometric detector GCMS-QP2010 (Shimadzu, Japan). Mass spectrometer was used in the electron impact ionization mode at $70 \mathrm{eV}$, 
mass range was selected within $\mathrm{m} / \mathrm{z}$ 30-400. Volatile compounds were separated using the RTX-5MS column (30 m length, $0.25 \mathrm{~mm}$ i.d., $0.25 \mu \mathrm{m}$ film thickness), Restek, USA. Carrier gas, helium, was adjusted to $1.2 \mathrm{ml} / \mathrm{min}$ flow rate. Split mode injection was used at a split ratio of 1:10; injector temperature was $240{ }^{\circ} \mathrm{C}$. The oven temperature was maintained at $60{ }^{\circ} \mathrm{C}$ for $3 \mathrm{~min}$, then raised to $78{ }^{\circ} \mathrm{C}$ at rate of $2{ }^{\circ} \mathrm{C} / \mathrm{min}$, then raised to $126^{\circ} \mathrm{C}$ at rate of $8{ }^{\circ} \mathrm{C} / \mathrm{min}$, then raised to $150{ }^{\circ} \mathrm{C}$ at rate $2{ }^{\circ} \mathrm{C} / \mathrm{min}$ and kept for $5 \mathrm{~min}$, and finally raised to $285^{\circ} \mathrm{C}$ at rate $10{ }^{\circ} \mathrm{C} / \mathrm{min}$ and held for $8 \mathrm{~min}$. Three replicates of each sample were run using GC/MS.

Quantitative analysis was performed according to the integrated peak areas of essential oils chromatograms. Identification of the compounds was performed according to the mass spectra and NIST spectra library (USA); the linear retention indices (LRI) were also calculated and compared to LRI described by Adams. ${ }^{22}$ LRI were determined using homologous series of normal n-alkanes, $\mathrm{C}_{8}-\mathrm{C}_{24}$ (Sigma Chemical Co., St. Louis, MO) in a temperature-programmed GC run, as described above.

The quantitative composition of the essential oils of different extractions was expressed in arbitrary units of peak area in GC chromatogram for the quantitative analysis interpretation clarity: the same amount of a compound in different samples will yield different percentage value because of different total amount of all compounds in the compared samples, making comparison of the percentage values intricate. Anyway, percentage amount will be used in the discussion, because of the comparison of the results with the data of other authors.

\section{4. Statistical Analysis}

The results are provided as a mean of three chromatographic separations. Standard deviations and R-squared values $\left(\mathrm{R}^{2}\right)$ were calculated using spreadsheet software (Excel ${ }^{\circledR}$, Microsoft, USA). To determine whether differences among averages were significant, single-factor

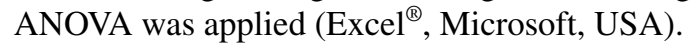

\section{Results and Discussion}

Literature data about the quantitative composition of Bidens tripartita L. volatiles using supercritical fluid extraction are scarce. Mostly analyses were performed on flavonoids content. ${ }^{17,18}$ Tomczykowa et al. ${ }^{1}$ analyzed freshly picked-up herb and dried flowers samples, prepared using hydrodistillation. Detailed analysis of volatile compounds composition was under the scope of our study. The main compounds identified in the essential oils of $B$. tripartita, extracted using SFE, were the following: $\alpha$-pinene (MS match 97\%, LRI 926), p-cymene (MS match 95\%, LRI 1017), $\beta$-ocimene (MS match 97\%, LRI 1031), $\beta$-elemene (MS match 97\%, LRI 1381). The chromatographic profile of $B$. tripartita $\mathrm{L}$. volatile compounds is presented in Figure 2.

\section{1. Dependence of Essential Oils Recovery on Solid Phase Desorption Solvent}

One of the factors affecting the recovery of analytes using solid phase trapping is the trap rinse solvent, which is used to desorb the analytes. Many studies were performed on pesticides recoveries using different trap rinse solvents and trap adsorbents, ${ }^{7,23-25}$ however no study on the volatiles or essential oils recoveries was carried out yet. The study of Lehotay and Valverde-Garcia ${ }^{24}$ on SFE of pesticides showed, that recovery of extraction was dependent not only on the trap rinse solvent, but also on the sample matrix. In our study the comparison of desorption

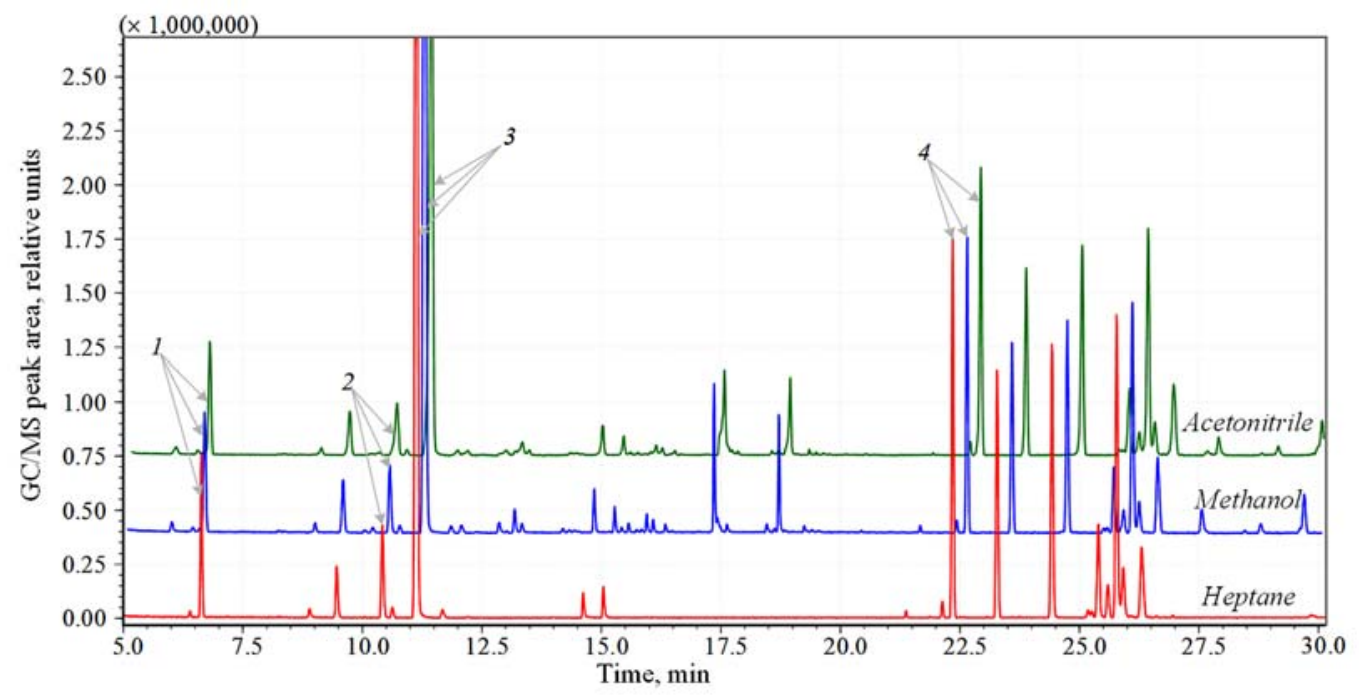

Figure 2. The chromatographic profile of $B$. tripartita L. volatile compounds obtained by supercritical fluid extraction using different trap rinse solvents $(1-\alpha$-pinene; 2 - $p$-cymene; 3 - $\beta$-ocimene; 4 - $\beta$-elemene) 
(solid phase rinsing) efficiency using three different organic solvents, heptane, methanol and acetonitrile, was carried out. Heptane was selected as a rinse solvent for the ODS solid phase extraction trap due to its nonpolar nature, high volatility and common use as a solvent of essential oils in GC analysis. Methanol and acetonitrile were selected as the most common eluents from the reversed phase stationary phases used in HPLC, although their polarity is much higher comparing with heptane.

$\beta$-Ocimene was the main compound (40-46\%) in all extracts despite the solvent used. The amounts of other three compounds desorbed using different solvents were in the following order: $\beta$-elemene $>\alpha$-pinene $>p$-cymene. No significant difference between the amounts of $\alpha$-pinene was observed, while heptane desorbed significantly higher amounts (12-31\%) of other compounds. The chromatographic profile of volatile compounds using different rinse solvents is presented in Figure 2. SFE extractor allows rinsing the essential oils from the trap in several substeps. Two substeps were used in our study. Neither of the solvents desorbed $100 \%$ of trapped compounds during the $1^{\text {st }}$ rinsing cycle.

The profiles of chromatograms obtained with different rinse solvents slightly differed. The extract obtained using methanol contained higher number of minor volatile compounds. As our scope was to analyse the recovery of the main compounds in the volatile fraction of $B$. tripartita L., heptane was selected for the further experiments, as the highest recovery providing desorption solvent.

\section{2. Dependence of Extraction Recovery on the Sample Amount Used}

$\beta$-Ocimene was predominant in all extracts prepared from the different amounts of dried B. tripartita L. samples. The amount of this compound varied from $23 \%$ to $46 \%$. The compounds identified in this study were also found in B. tripartita $\mathrm{L}$. samples by Tomczykowa et al., ${ }^{1}$ while compositions were different: the main compound found by Tomczykowa et al. ${ }^{1}$ in dried flowers was $p$ cymene $(16.6 \%)$; in fresh herb - allo-ocimene (38.3\%) and $\beta$-ocimene (30.6\%). In our study allo-ocimene was not found. The result may be different due to the different extraction technique. High amount of allo-ocimene is accumulated only in the fresh herb (amount of this compound in dried flower was $2.2 \%),{ }^{1}$ and may degrade or evaporate during the drying.

The percentage composition of $B$. tripartita extract was dependent on the amount of the material used for the extraction (Figure 3). The study showed a logarithmic function $y=105.2 \ln x+34.4$, which gives the best fit describing relationship between the amount of sample material used for SFE and the total amount of essential oils extracted. Only 6 compounds were extracted using $0.10 \mathrm{~g}$ of the sample, while number of compounds tripled (to 18) using $0.80 \mathrm{~g}$ of the sample. Dependence of the total area of peaks in GC chromatogram on the sample amount reflected this tendency as well (Figure 3).

The correlation between the amount of the extracted major compounds and the amount of the sample material used was observed (Figure 3 ). The changes of extracted $\beta$ elemene amount is described by a linear dependence on the sample amount $\left(y=45.4 x+1.4, \mathrm{R}^{2}=0.98\right)$, while other compounds ( $\alpha$-pinene, $p$-cymene, and $\beta$-ocimene) showed relationships, approximated as polynomials. These results can be explained by different interactions between volatile compounds and the trap adsorbent or/and limited sorption capacity of the adsorbent. Consequently the ratio of the sample amount to the adsorbent amount must be optimized in order to increase recovery and reveal qualitative composition of the volatiles.

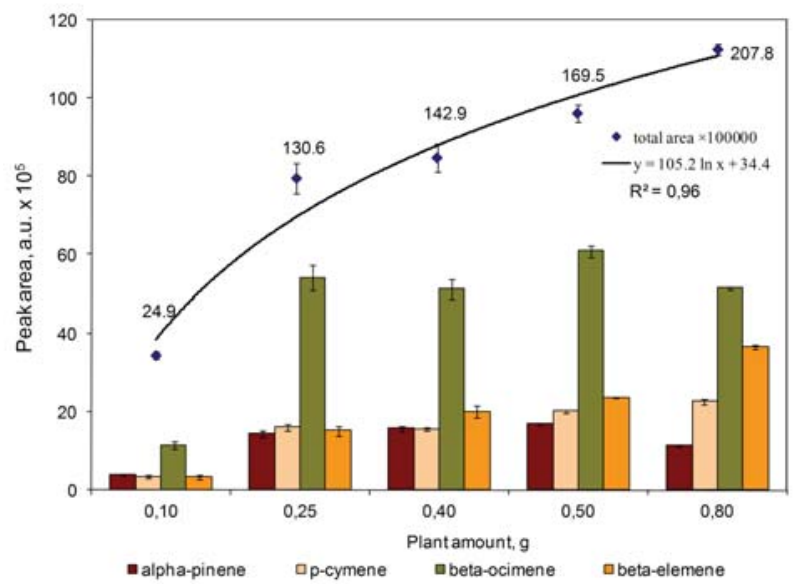

Figure 3. Dependence of the total amount of extracted essential oils (together with some compounds of the essential oils) on the sample amount used for the extraction

The volatiles compositions obtained using $0.25 \mathrm{~g}$ and $0.40 \mathrm{~g}$ of the plant material were similar, except the amount of $\beta$-elemene, which was significantly different. In total 12 and 14 different compounds were extracted from $0.25 \mathrm{~g}$ and $0.40 \mathrm{~g}$ of the plant, respectively. Nevertheless, $0.50 \mathrm{~g}$ of plant material allowed extraction of 14 various compounds, significantly higher amounts of $\beta$-pinene and $p$-cymene were obtained. The sample amount of $0.50 \mathrm{~g}$ was selected for the further studies. In summary, the lower amount of plant material can be used for extraction of the main compounds, while higher amount of the plant material results in more precise qualitative description of the minor volatiles compounds in the sample (including trace compounds). This is more suitable for qualitative but not for quantitative analysis. Nevertheless it should be kept in mind, that too small or too big amount of plant material used for extraction may lead to the waste of energy or/and plant material due to the excess of the adsorption capacity of the solid phase extraction trap. According to Turner et al., ${ }^{7}$ losses of analytes may occur due to 
the overloading of trapping material with co-extracted matrix components (for example, fat), not only due to the high amounts of analytes. In our case it can be waxes accumulating on the surface of plants.

\section{3. Recovery of the Main Compounds of $B$. tripartita L. by Means of Multiple Extraction}

The supercritical fluid extraction-after-extraction (3 times) of B. tripartita L. raw material was carried out. The distribution of the main volatile compounds in the extracts of the $1^{\text {st }}$ and $2^{\text {nd }}$ rinse substeps are presented in Table 1 . It can be seen that $10 \%\left(1^{\text {st }}\right.$ extraction $)$ and $17 \%\left(2^{\text {nd }}\right.$ and $3^{\text {rd }}$ extractions) of volatiles are eluted after $2^{\text {nd }}$ rinse substep. These data were used for analysis of the recovery of extraction: recovery of volatile compounds reached only $50.7 \%$ during the first extraction of the sample and trap rinse $1^{\text {st }}$ substep. Significant quantities, i.e. $19.2 \%$ and $16.8 \%$ of volatile compounds were extracted during the $2^{\text {nd }}$ and $3^{\text {rd }}$ extraction, respectively. This could be due to the fact, that some compounds were better encapsulated in the plant cells and longer extraction time was needed for the extraction.

Total amount of $\alpha$-pinene, $p$-cymene, $\beta$-ocimene, $\beta$ elemene in the samples after three extractions is presented in Figure 4. As it was mentioned before $\alpha$-pinene, $p$ cymene, $\beta$-ocimene, and $\beta$-elemene were the main com-

Table 1. Distribution of the main compounds in the essential oils of Bidens tripartita L. after three extractions of the same sample using two rinse substeps

\begin{tabular}{|c|c|c|c|c|c|c|c|c|c|c|}
\hline \multirow{2}{*}{$\begin{array}{l}\text { Identified } \\
\text { compound }\end{array}$} & \multicolumn{3}{|c|}{$\begin{array}{l}\text { GC/MS peak area, } \\
\text { relative units }\end{array}$} & \multicolumn{3}{|c|}{$\begin{array}{c}\text { Percentage distribution } \\
\text { including all extractions, \% }\end{array}$} & \multicolumn{3}{|c|}{$\begin{array}{c}\text { Percentage distribution } \\
\text { between rinse substeps, \% }\end{array}$} & \multirow{2}{*}{$\begin{array}{c}\text { Comparison } \\
\text { between } \\
\text { extractions, } \\
\%\end{array}$} \\
\hline & $\begin{array}{l}1^{\text {st }} \text { rinse } \\
\text { substep }\end{array}$ & $\begin{array}{l}2^{\text {nd }} \text { rinse } \\
\text { substep }\end{array}$ & sum & $\begin{array}{l}1^{\text {st }} \text { rinse } \\
\text { substep }\end{array}$ & $\begin{array}{l}2^{\text {nd }} \text { rinse } \\
\text { substep }\end{array}$ & sum & $\begin{array}{l}1^{\text {st }} \text { rinse } \\
\text { substep }\end{array}$ & $\begin{array}{l}2^{\text {nd }} \text { rinse } \\
\text { substep }\end{array}$ & sum & \\
\hline & \multicolumn{9}{|c|}{$1^{\text {st }}$ extraction } & $1^{\text {st }}$ and $2^{\text {nd }}$ \\
\hline$\alpha$-pinene & 113.4 & 19.0 & 132.4 & 3.4 & 0.6 & 4.0 & 6.8 & 1.1 & 8.0 & 20.3 \\
\hline p-cymene & 126.1 & 12.1 & 138.2 & 3.8 & 0.4 & 4.1 & 7.6 & 0.7 & 8.3 & 46.7 \\
\hline$\beta$-ocimene & 657.9 & 84.8 & 742.8 & 19.7 & 2.5 & 22.2 & 39.7 & 5.1 & 44.8 & 57.9 \\
\hline$\beta$-elemene & 116.5 & 0.0 & 116.5 & 3.5 & 0.0 & 3.5 & 7.0 & 0.0 & 7.0 & 59.7 \\
\hline \multirow[t]{2}{*}{ all compounds } & 1488.7 & 169.0 & 1657.7 & 50.7 & 5.8 & 56.4 & 89.8 & 10.2 & 100.0 & 62.1 \\
\hline & \multicolumn{9}{|c|}{$2^{\text {nd }}$ extraction } & $2^{\text {nd }}$ and $3^{\text {rd }}$ \\
\hline$\alpha$-pinene & 90.4 & 22.1 & 112.5 & 2.7 & 0.7 & 3.4 & 5.5 & 1.3 & 6.8 & 27.5 \\
\hline p-cymene & 67.2 & 15.1 & 82.4 & 2.0 & 0.5 & 2.5 & 4.1 & 0.9 & 5.0 & 0.2 \\
\hline$\beta$-ocimene & 277.0 & 57.4 & 334.3 & 8.3 & 1.7 & 10.0 & 16.7 & 3.5 & 20.2 & 5.9 \\
\hline$\beta$-elemene & 47.0 & 0.0 & 47.0 & 1.4 & 0.0 & 1.4 & 2.8 & 0.0 & 2.8 & 21.2 \\
\hline \multirow[t]{2}{*}{ all compounds } & 564.9 & 121.8 & 686.8 & 19.2 & 4.1 & 23.4 & 82.3 & 17.7 & 100.0 & 12.7 \\
\hline & \multicolumn{9}{|c|}{$3^{\text {rd }}$ extraction } & $1^{\mathrm{st}}$ and $3^{\text {rd }}$ \\
\hline$\alpha$-pinene & 65.5 & 17.0 & 82.5 & 2.0 & 0.5 & 2.5 & 4.0 & 1.0 & 5.0 & 42.2 \\
\hline p-cymene & 67.1 & 12.1 & 79.2 & 2.0 & 0.4 & 2.4 & 4.0 & 0.7 & 4.8 & 46.8 \\
\hline$\beta$-ocimene & 260.6 & 47.4 & 307.9 & 7.8 & 1.4 & 9.2 & 15.7 & 2.9 & 18.6 & 60.4 \\
\hline$\beta$-elemene & 37.0 & 0.0 & 37.0 & 1.1 & 0.0 & 1.1 & 2.2 & 0.0 & 2.2 & 68.2 \\
\hline all compounds & 493.4 & 101.0 & 594.5 & 16.8 & 3.4 & 20.2 & 83.0 & 17.0 & 100.0 & 66.9 \\
\hline
\end{tabular}

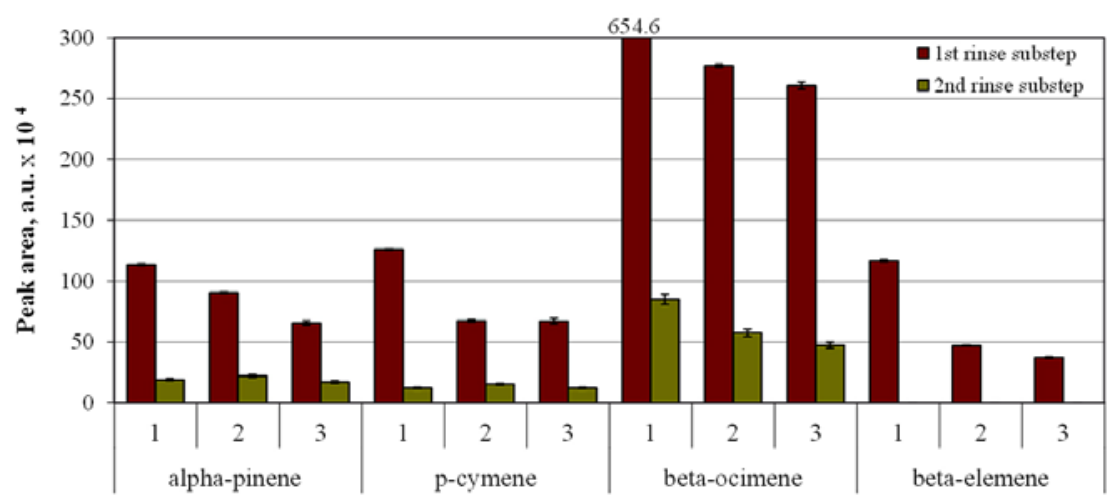

Figure 4. Distribution of the main compounds of the volatile composition of Bidens tripartita L. after three extractions of the same sample using two rinse substeps 
pounds of $B$. tripartita L., and these compounds constituted $68 \%, 85 \%$, and $87 \%$ respectively of all compounds extracted during the $1^{\text {st }}, 2^{\text {nd }}$, and $3^{\text {rd }}$ extractions.

The differences in the amounts of the main compounds were observed not only between extraction-afterextraction, but also between rinse substeps of the trap (Table 1 and Figure 4). It is evident, that only $\beta$-elemene is completely desorbed (rinsed) from the trap at the $1^{\text {st }}$ substep, while only $82-90 \%$ of other compounds are desorbed during this rinse substep.

The quantitative composition difference between $2^{\text {nd }}$ and $3^{\text {rd }}$ extractions varied in the following order: $27.5 \%$ $(\alpha$-pinene $)>21.2 \%(\beta$-elemene $)>5.9 \%(\beta$-ocimene $)>$ $0.2 \%$ ( $p$-cymene). The highest differences between the $1^{\text {st }}$ and $2^{\text {nd }}$ extractions were obtained for $\beta$-elemene (59.7\%), $\beta$-ocimene (57.9\%), and $p$-cymene (46.7\%), while $\alpha$-pinene differed only $20.3 \%$ (Table 1 ).

\section{Conclusions}

The investigation of recovery of volatiles of Bidens tripartita using solid-phase extraction trap in supercritical fluid extraction was performed. Both qualitative and quantitative compositions of volatile compounds obtained using supercritical fluid extraction were dependent on the rinse solvent of the solid trap and amount of plant material used for extraction. Heptane showed the best characteristics for the extraction of $B$. tripartita volatiles. Anyway, it is recommended that amount of the biological sample used for the extraction would be optimized before analysis for every particular sample (plant, plant botanical part, extracted material particle size, etc.). The study has shown that kinetics of extraction of different components of the essential oils differ considerably. For higher recoveries and correct determination of qualitative composition of the volatiles, multiple extractions of the plant material are recommended. The repeated extraction experiments revealed that essential oils were locked in the plant cells at various extents and their extraction kinetics is different. The recovery of B. tripartita L. volatiles obtained by supercritical fluid extraction during the $1^{\text {st }}$ extraction, using one substep trap rinsing, was $50.7 \%$.

\section{Acknowledgements}

We wish to thank Prof. O. Ragažinskiene (Head of the Sector of Medicinal Plants, Kaunas Botanical Garden of Vytautas Magnus University) for providing the B. tripartita L. raw material.

This study was supported by postdoctoral research fellowship. Postdoctoral fellowship is being funded by European Union Structural Funds project "Postdoctoral Fellowship Implementation in Lithuania".

\section{References}

1. M. Tomczykowa, J. Gudej, T. Majda, J. Góra, J. Essent. Oil Res., 2005, 17, 632-635. http://dx.doi.org/10.1080/10412905.2005.9699018

2. W. Guan, S. Li, R. Yan, S. Tang, C. Quan, Food Chem., 2007, 101, 1558-1564.

http://dx.doi.org/10.1016/j.foodchem.2006.04.009

3. O. O. Okoh, A. P. Sadimenko, A. J. Afolayan, Food Chem., 2010, 120, 308-312. http://dx.doi.org/10.1016/j.foodchem.2009.09.084

4. P. Bhattacharjee, A. Kshirsagar, R. S. Singhal, Food Chem., 2005, 91, 255-259.

http://dx.doi.org/10.1016/j.foodchem.2004.01.062

5. E. Alissandrakis, D. Daferera, P. A. Tarantilis, M. Polissiou, P. C. Harizanis, Food Chem., 2003, 82, 575-582. http://dx.doi.org/10.1016/S0308-8146(03)00013-X

6. S. M. Pourmortazavi, S. S. Hajimirsadeghi, J. Chromatogr. A, 2007, 1163, 2-24. http://dx.doi.org/10.1016/j.chroma.2007.06.021

7. C. Turner, C. S. Eskilsson, E. Björklund, J. Chromatogr. A, 2002, 947, 1-22. http://dx.doi.org/10.1016/S0021-9673(01)01592-8

8. L. A. Sarmento, C. B. Spricigo, J. C. C. Petrus, L. H. C. Carlson, R. A. F. Machado, J. Membr. Sci., 2004, 237, 71-76. http://dx.doi.org/10.1016/j.memsci.2004.02.021

9. L. H. C. Carlson, A. Bolzan, R. A. F. Machado, J. Supercrit. Fluids, 2005, 34, 143-147.

http://dx.doi.org/10.1016/j.supflu.2004.11.007

10. J. M. L. N. de Moura, L. A. G. Goncalves, L. A. V. Sarmento, J. C. C. Petrus, J. Membr. Sci., 2007, 299, 138-145. http://dx.doi.org/10.1016/j.memsci.2007.04.035

11. J. L. Benitez, A. Forster, D. De Keukeleire, M. Moir, F. R. Sharpe, L. C. Verhagen, K. T. Westwood, (eds.) European Brewery Convention Manual of Good Practice: Hops and Hop products. Fachverlag Hans Carl, Nurnberg, Germany, 1997.

12. F. Van Opstaele, K. Goiris, G. De Rouck, G. Aerts, L. De Cooman, J. Supercrit. Fluids, 2012, 69, 45-56. http://dx.doi.org/10.1016/j.supflu.2012.05.009

13. F. Van Opstaele, K. Goiris, G. De Rouck, G. Aerts, L. De Cooman, J. Supercrit. Fluids, 2012, 71, 147-161. http://dx.doi.org/10.1016/j.supflu.2012.06.004

14. G. Brunner, J. Food Eng., 2005, 67, 21-33. http://dx.doi.org/10.1016/j.jfoodeng.2004.05.060

15. Q. Lang, C. M. Wai, Talanta, 2001, 53, 771-782. http://dx.doi.org/10.1016/S0039-9140(00)00557-9

16. S. Espinosa, M. S. Diaz, E. A. Brignole, J. Supercrit. Fluids, 2008, 45, 213-219. http://dx.doi.org/10.1016/j.supflu.2008.02.006

17. M. Wolniak, M. Tomczykowa, M. Tomczyk, J. Gudej, I. Wawer, Acta Pol. Pharm. - Drug Res., 2007, 63, 441-447.

18. O. N. Pozharitskaya, A. N. Shikov, M. N. Makarova, V. M. Kosman, N. M. Faustova, S. V. Tesakova, V. G. Makarov, B. Galambosi, Phytomedicine, 2010, 17, 463-468. http://dx.doi.org/10.1016/j.phymed.2009.08.001 
19. M. Tomczykowa, M. Tomczyk, P. Jakoniuk, E. Tryniszewska, Folia Histochem. Cyto., 2008, 46, 389-393. http://dx.doi.org/10.2478/v10042-008-0082-8

20. W. Qu, Z. Pan, H. Ma, J. Food Eng., 2010, 99, 16-23. http://dx.doi.org/10.1016/j.jfoodeng.2010.01.020

21. R. González-Montelongo, M. Gobo, M. González, Food Chem., 2010, 119, 1030-1039.

http://dx.doi.org/10.1016/j.foodchem.2009.08.012

22. R. P. Adams, Identification of essential oil components by gas chromatography/quadrupole mass spectroscopy. 4th edn. Allured Publishing Corporation, Illinois, 2007, pp. 804.
23. C. Quan, S. Li, S. Tian, H. Xu, A. Lin, L.Gu, J. Supercrit. Fluids, 2004, 31, 149-157.

http://dx.doi.org/10.1016/j.supflu.2003.11.003

24. S. J. Lehotay, A. Valverde-Garcia. J. Chromatogr. A, 1997, 765, 69-84.

http://dx.doi.org/10.1016/S0021-9673(96)00846-1

25. A. Koinecke, R. Kreuzig, M. Bahadir, J. Chromatogr. A, 1997, 786, 155-161.

http://dx.doi.org/10.1016/S0021-9673(97)00689-4

\section{Povzetek}

V sklopu študije ekstrakcije hlapnih komponent iz Bidens tripartita L. z uporabo superkritičnega $\mathrm{CO}_{2}$ smo proučevali vpliv treh dejavnikov: topila (heptan, metanol, acetonitril), ki se uporablja za izpiranje analitov iz pasti, mase rastlinskega materiala uporabljenega za ekstrakcijo in uporabo večkratnih ekstrakcij istega rastlinskega materiala. $\mathrm{V}$ vseh ekstraktih so prevladovali $\alpha$-pinen, p-cimen, $\beta$-ocimen in $\beta$-elemen, največ pa je bilo $\beta$-ocimena (40-46\%). Različna topila niso signifikantno vplivala na količino ekstrahiranega $\alpha$-pinena. Potrjeno je bilo, da masa rastlinskega materiala uporabljenega za ekstrakcijo vpliva na kvalitativno in kvantitativno sestavo hlapnih komponent ekstrakta. Tudi med prvo in večkratnimi zaporednimi ekstrakcijami iz istega rastlinskega materiala so bile ugotovljene razlike $\mathrm{v}$ sestavi glavnih komponent. 